\title{
8. Inequality and Economic Growth
}

JOSEPH E. STIGLITZ

\section{Introduction}

IN THE middle of the twentieth century, it came to be believed that "a rising tide lifts all boats': economic growth would bring increasing wealth and higher living standards to all sections of society. At the time, there was some evidence behind that claim. In industrialised countries in the 1950s and 1960s every group was advancing, and those with lower incomes were rising most rapidly.

In the ensuing economic and political debate, this 'rising-tide hypothesis' evolved into a much more specific idea, according to which regressive economic policies-policies that favour the richer classes-would end up benefiting everyone. Resources given to the rich would inevitably 'trickle down' to the rest. It is important to clarify that this version of old-fashioned 'trickle-down economics' did not follow from the postwar evidence. The 'rising-tide hypothesis' was equally consistent with a 'trickle-up' theory - give more money to those at the bottom and everyone will benefit; or with a 'build-out from the middle' theory-help those at the centre, and both those above and below will benefit.

Today the trend to greater equality of incomes which characterised the postwar period has been reversed. Inequality is now rising rapidly. Contrary to the rising-tide hypothesis, the rising tide has only lifted the large yachts, and many of the smaller boats have been left dashed on the rocks. This is partly because the extraordinary growth in top incomes has coincided with an economic slowdown.

The trickle-down notion-along with its theoretical justification, marginal productivity theory - needs urgent rethinking. That theory attempts both to explain inequality - why it occurs - and to justify it-why it would be beneficial for the economy as a whole. This chapter looks critically at both claims. It argues in favour of alternative explanations of inequality, with particular reference to the theory of rent-seeking and to the influence of institutional and political factors, which have shaped labour markets and patterns of remuneration. And it shows that, far from being either necessary or good for economic growth, excessive inequality tends to lead to weaker economic performance. In light of this, it argues for a range of policies that would increase both equity and economic well-being.

\section{The great rise of inequality}

Let us start by examining the ongoing trends in income and wealth. In the past three decades, those at the top have done very well, especially in the

The Author 2016. The Political Quarterly The Political Quarterly Publishing Co. Ltd. 2016 Published by John Wiley \& Sons Ltd, 9600 Garsington Road, Oxford OX4 2DQ UK and 350 Main Street, Malden, MA 02148, USA 
US. Between 1980 and 2014, the richest 1 per cent have seen their average real income increase by 169 per cent (from $\$ 469,403$, adjusted for inflation, to $\$ 1,260,508$ ) and their share of national income more than double, from 10 per cent to 21 per cent. The top 0.1 per cent have fared even better. Over the same period, their average real income increased by 281 per cent (from $\$ 1,597,080$, adjusted for inflation, to $\$ 6,087,113$ ) and their share of national income almost tripled, from 3.4 to 10.3 per cent. $^{1}$

Over the same thirty-four years, median household income grew by only 11 per cent. And this growth actually occurred only in the very first years of the period: by 2014 it was only .7 per cent higher than in 1989, after peaking in $1999 .^{2}$ But even this underestimates the extent to which those at the bottom have suffered-their incomes have only done as well as they have because hours worked have increased. Median hourly compensation (adjusted for inflation) increased by only 9 per cent from 1973 to 2014, even though at the same time productivity grew by 72.2 per cent (Figure 1). (To understand how significant this divergence of productivity and wages is, consider that from 1948 to 1973 both increased at the same pace, about doubling over the period. $)^{3}$ And these statistics underestimate the true deterioration in workers' wages, for education levels have increased (the percentage of Americans who are college graduates has nearly doubled since 1980, to more than 30 per cent), ${ }^{4}$ so that one should have expected a significant increase in wage rates. In fact, average real hourly wages for all Americans with only a high school diploma have decreased in the past three decades. ${ }^{5,6}$
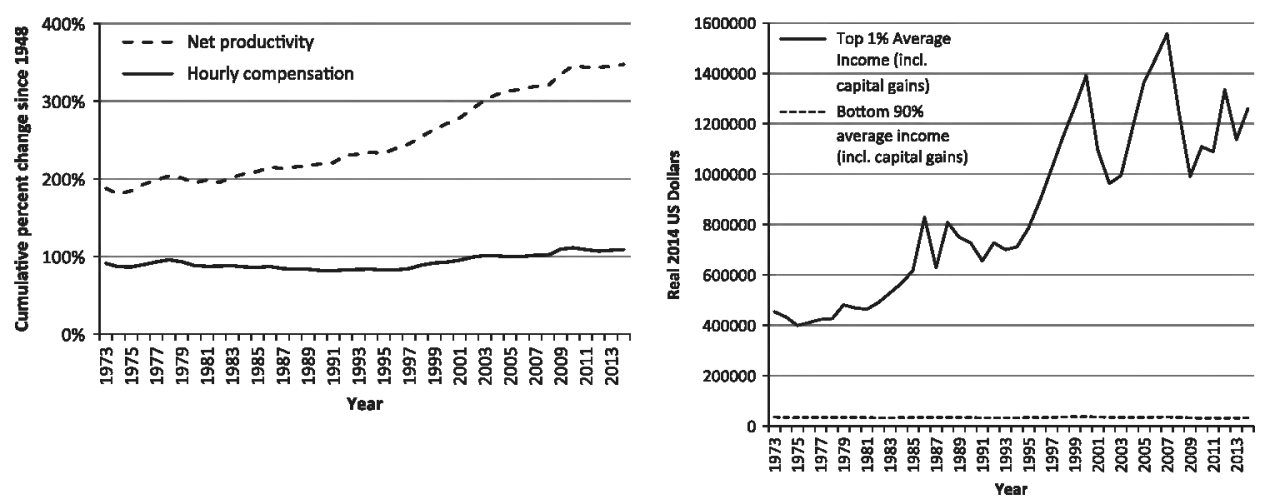

Figure 1: Wages, productivity and average incomes in the US (1973-2014)

Notes: (left panel) Data are for average hourly compensation of production/nonsupervisory workers in the private sector and net productivity of the total economy. 'Net productivity' is the growth of output of goods and services minus depreciation per hour worked. EPI analysis of data from the BEA and BLS (see technical appendix for more detailed information).

Sources: Economic Policy Institute (left panel); The World Wealth and Income Database. Facundo Alvaredo, Tony Atkinson, Thomas Piketty, Emmanuel Saez and Gabriel Zucman (right panel) 
In the first three years of the so-called recovery from the Great Recession of 2008-2009 - in other words, since the US economy returned to growthfully 91 per cent of the gains in income went to the top 1 per cent. By 2014, the rest of the income distribution had experienced a bit more of a boost, but even accounting for that, 58 per cent of the gains in total income have gone to the top 1 per cent since 2009. (During that period, the income of the bottom 99 per cent has grown by just 4 per cent.) ${ }^{7}$ Presidents Bush and Obama both tried a trickle-down strategy-giving large amounts of money to the banks and the bankers. The idea was simple: by saving the banks and bankers, all would benefit. The banks would restart lending. The wealthy would create more jobs. This strategy, it was argued, would be far more efficacious than helping homeowners, businesses or workers directly. The US Treasury typically demands that when money is given to developing countries, conditions be imposed on them to ensure not only that the money is used well, but also that the country adopts economic policies that (according to the Treasury's economic theories) will lead to growth. But no conditions were imposed on the banks - not even, for example, requirements that they lend more or stop abusive practices. The rescue worked in enriching those at the top; but the benefits did not trickle down to the rest of the economy.

The Federal Reserve, too, tried trickle-down economics. One of the main channels by which quantitative easing was supposed to rekindle growth was by leading to higher stock market prices, which would generate higher wealth for the very rich, who would then spend some of that, which in turn would benefit the rest.

As Yeva Nersisyan and Randall Wray argue in their chapter in this volume, both the Fed and the Administration could have tried policies that more directly benefited the rest of the economy: helping homeowners, lending to small and medium-sized enterprises and fixing the broken credit channel. These trickle-down policies were relatively ineffective - one reason why seven years after the US slipped into recession, the economy was still not back to health.

Wealth is even more concentrated than income-by one estimate more than ten times so. The wealthiest 1 per cent of Americans hold 41.8 per cent of the country's wealth; the top 0.1 per cent alone control more than 22 per cent of total wealth. ${ }^{8}$ Just one example of the extremes of wealth in America is the Walton family: the six heirs to the Walmart empire command a wealth of $\$ 145$ billion, which is equivalent to the net worth of $1,782,020$ average American families. ${ }^{9}$

Wealth inequality too is on the upswing. For the four decades before the Great Recession, the rich were getting wealthier at a more rapid pace than everyone else. Between 1978 and 2013 the share of wealth owned by the top 1 per cent rose dramatically, from less than 25 per cent to its current level above 40 per cent; the share of the top 10 per cent from about two-thirds to well over three-quarters. ${ }^{10}$ By 2010, the crisis had depleted some of the 
richest Americans' wealth because of the decline in stock prices, but many Americans also had had their wealth almost entirely wiped out as their homes lost value. After the crisis, the average wealthiest 1 per cent of households still had 165 times the wealth of the average American in the bottom 90 per cent-more than double the ratio of thirty years ago. ${ }^{11}$ In the years of 'recovery', as stock market values rebounded (in part as a result of the Fed's lopsided efforts to resuscitate the economy through increasing the balance sheet of the rich), the rich have regained much of the wealth that they had lost; the same did not happen to the rest of the country. ${ }^{12}$

Inequality plays out along ethnic lines in ways that should be disturbing for a country that had begun to see itself as having won out against racism. Between 2005 and 2009, a huge number of Americans saw their wealth drastically decrease. The net worth of the typical white American household was down substantially, to $\$ 113,149$ in 2009 , a 16 per cent loss of wealth from 2005. But the recession was much worse for other groups. The typical African American household lost 53 per cent of its wealth-putting its assets at a mere 5 per cent of the median white American's. The typical Hispanic household lost 66 per cent of its wealth. ${ }^{13}$

Probably the most invidious aspect of America's inequality is that of opportunities: in the US a young person's life prospects depend heavily on the income and education of his or her parents, even more than in other advanced countries. ${ }^{14}$ The 'American dream' is largely a myth.

A number of studies have noted the link between inequality of outcomes and inequality of opportunities. ${ }^{15}$ When there are large inequalities of income, those at the top can buy for their offspring privileges not available to others, and they often come to believe that it is their right and obligation to do so. And, of course, without equality of opportunity those born in the bottom of the distribution are likely to end up there: inequalities of outcomes perpetuate themselves. This is deeply troubling: given our low level of equality of opportunity and our high level of inequality of income and wealth, it is possible that the future will be even worse, with still further increases in inequality of outcome and still further decreases in equality of opportunity.

\section{A generalised international trend}

While the US has been winning the race to be the most unequal country (at least within developed economies), much of what has just been described for it has also been going on elsewhere. In the past twenty-five to thirty years the Gini index - the widely used measure of income inequality-has increased by roughly 29 per cent in the United States, 17 per cent in Germany, 9 per cent in Canada, 14 per cent in UK, 12 per cent in Italy and 11 per cent in Japan (Figure 2). ${ }^{16}$ The more countries follow the American economic model, the more the results seem to be consistent with what has occurred in the United States. The UK has now achieved the second highest level of inequality among the countries of Western Europe and North 


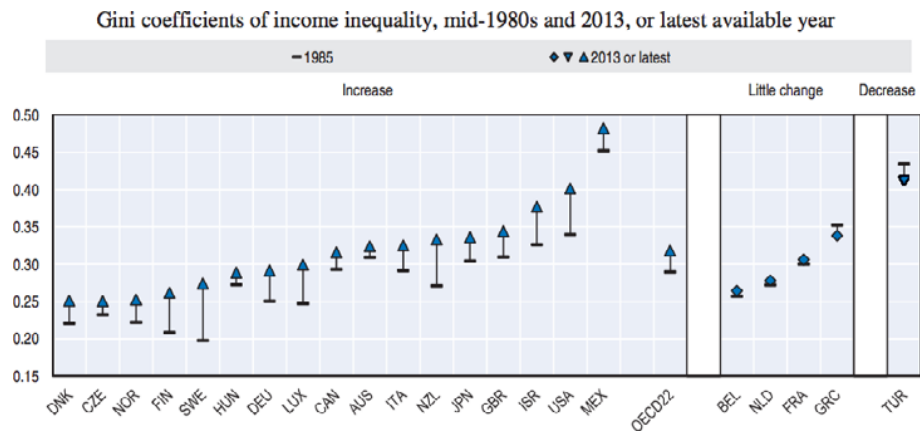

Figure 2: Gini coefficient of income inequality in OECD countries (after-tax and transfer)

Note: income refers to disposable income adjusted for household size.

Source: OECD, In It Together: Why Less Inequality Benefits All, OECD, Paris, 2015, p. 24

America, a marked change from its position before the Thatcher era (Figures 2 and 3). Germany, which had been among the most equal countries within the OECD, now ranks in the middle.

The enlargement of the share of income appropriated by the richest 1 per cent has also been a general trend, and in Anglo-Saxon countries it started earlier and it has been more marked than anywhere else (Figure 3). In rich countries, such as the US, the concentration of wealth is even more pronounced than that of income, and has been rising too. For instance, in the UK the income share of the top 1 per cent went up from 5.7 per cent in 1978 to 14.7 per cent in 2010, while the share of wealth owned by the top 1 per cent surged from 22.6 per cent in 1970 to 28 per cent in 2010 and the
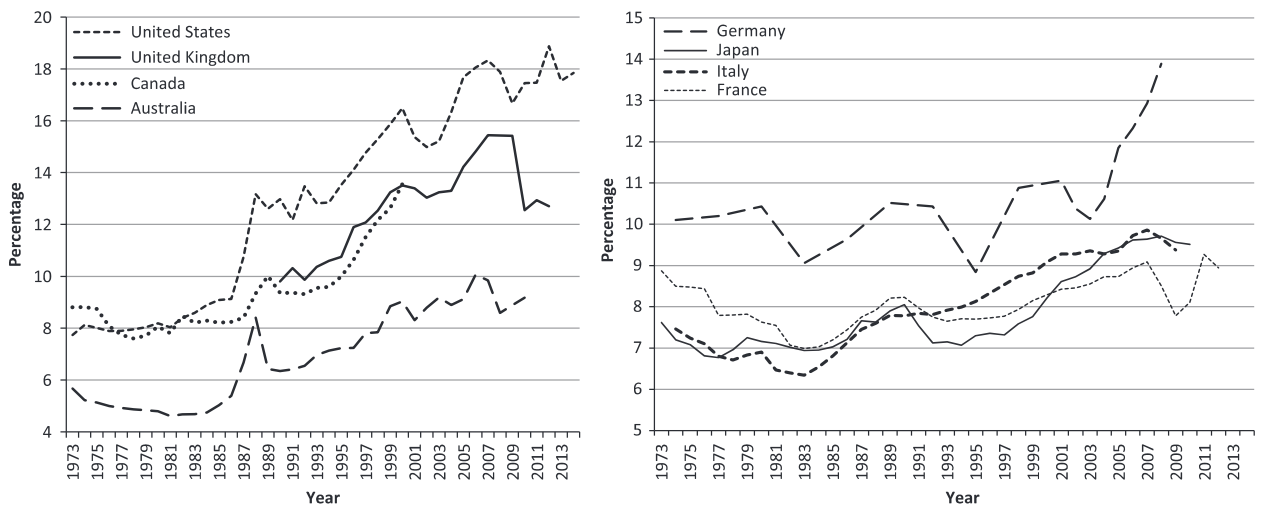

Figure 3: Income share of the richest 1 per cent in some major industrialised countries

Source: The World Wealth and Income Database (latest data available at http://www.wid. world/ (accessed 12 May 2016)) 
top 10 per cent's wealth share increased from 64.1 per cent to 70.5 per cent over the same period. ${ }^{17}$

Also disturbing are the patterns that have emerged in transition economies, which at the beginning of their movement to a market economy had low levels of inequality in income and wealth (at least according to available measurements). Today, China's inequality of income, as measured by its Gini coefficient, is roughly comparable to that of the United States and Russia. ${ }^{18}$ Across the OECD, since 1985 the Gini coefficient has increased in seventeen of twenty-two countries for which data is available, often dramatically (Figure 2).

Moreover, recent research by Piketty and his co-authors has found that the importance of inherited wealth has increased in recent decades, at least in the rich countries for which we have data. After displaying a decreasing trend in the first postwar period, the share of inheritance flows in disposable income has been increasing in the past decades. ${ }^{19}$

\section{Explaining inequality}

How can we explain these worrying trends? Traditionally, there has been little consensus among economists and social thinkers on what causes inequality. In the nineteenth century, they strived to explain and either justify or criticise the evident high levels of disparity. Marx talked about exploitation. Nassau Senior, the first holder of the first chair in economics, the Drummond Professorship at All Souls College, Oxford, talked about the returns to capital as a payment for capitalists' abstinence, for their not consuming. ${ }^{20}$ It was not exploitation of labour, but the just rewards for their forgoing consumption. Neoclassical economists developed the marginal productivity theory, which argued that compensation more broadly reflected different individuals' contributions to society.

While exploitation suggests that those at the top get what they get by taking away from those at the bottom, marginal productivity theory suggests that those at the top only get what they add. The advocates of this view have gone further: they have suggested that in a competitive market, exploitation (e.g. as a result of monopoly power or discrimination) simply couldn't persist, and that additions to capital would cause wages to increase, so workers would be better off thanks to the savings and innovation of those at the top.

More specifically, marginal productivity theory maintains that, due to competition, everyone participating in the production process earns remuneration equal to her or his marginal productivity. This theory associates higher incomes with a greater contribution to society. This can justify, for instance, preferential tax treatment for the rich: by taxing high incomes we would deprive them of the 'just deserts' for their contribution to society, and, even more importantly, we would discourage them from expressing their talent. ${ }^{21}$ Moreover, the more they contribute the harder they work and the more they save the better it is for workers, whose wages will rise as a result. 
The reason why these ideas justifying inequality have endured is that they have a grain of truth in them. Some of those who have made large amounts of money have contributed greatly to our society, and in some cases what they have appropriated for themselves is but a fraction of what they have contributed to society. But this is only a part of the story: there are other possible causes of inequality. Disparity can result from exploitation, discrimination and exercise of monopoly power. Moreover, in general, inequality is heavily influenced by many institutional and political factors industrial relations, labour market institutions, welfare and tax systems, for example - which can both work independently of productivity and affect productivity.

That the distribution of income cannot be explained just by standard economic theory is suggested by the fact that the before-tax and transfer distribution of income differs markedly across countries. France and Norway are examples of OECD countries that have managed by and large to resist the trend of increasing inequality (Figures 2 and 3). The Scandinavian countries have a much higher level of equality of opportunity, regardless of how that is assessed. Marginal productivity theory is meant to have universal application. Neoclassical theory taught that one could explain economic outcomes without reference, for instance, to institutions. It held that a society's institutions are simply a faßade; economic behaviour is driven by the underlying laws of demand and supply, and the economist's job is to understand these underlying forces. Thus, the standard theory cannot explain how countries with similar technology, productivity and per capita income can differ so much in their before-tax distribution.

The evidence, though, is that institutions do matter. Not only can the effect of institutions be analysed, but institutions can themselves often be explained, sometimes by history, sometimes by power relations and sometimes by economic forces (like information asymmetries) left out of the standard analysis. ${ }^{22}$ Thus, a major thrust of modern economics is to understand the role of institutions in creating and shaping markets. The question then is: what is the relative role and importance of these alternative hypotheses? There is no easy way of providing a neat quantitative answer, but recent events and studies have lent persuasive weight to theories putting greater focus on rent-seeking and exploitation. We shall discuss this evidence in the next section, before turning to the institutional and political factors which are at the root of the recent structural changes in income distribution.

\section{Rent-seeking and top incomes}

The term 'rent' was originally used to describe the returns to land, since the owner of the land receives these payments by virtue of his or his ownership and not because of anything he or she does. The term was then extended to include monopoly profits (or monopoly rents) - the income that one receives simply from control of a monopoly-and in general returns due to similar 
ownership claims. Thus, rent-seeking means getting an income not as a reward for creating wealth but by grabbing a larger share of the wealth that would have been produced anyway. Indeed, rent-seekers typically destroy wealth, as a by-product of their taking away from others. A monopolist who overcharges for her or his product takes money from those whom she or he is overcharging and at the same time destroys value. To get her or his monopoly price, she or he has to restrict production.

Growth in top incomes in the past three decades has been driven mainly in two occupational categories: those in the financial sector (both executives and professionals) and non-financial executives. ${ }^{23}$ Evidence suggests that rents have contributed on a large scale to the strong increase in the incomes of both.

Let us first consider executives in general. That the rise in their compensation has not reflected productivity is indicated by the lack of correlation between managerial pay and firm performance. As early as 1990 Jensen and Murphy, by studying a sample of 2,505 CEOs in 1,400 companies, found that annual changes in executive compensation did not reflect changes in corporate performance. ${ }^{24}$ Since then, the work of Bebchuk, Fried and Grinstein has shown that the huge increase in US executive compensation since 1993 cannot be explained by firm performance or industrial structure and that, instead, it has mainly resulted from flaws in corporate governance, which enabled managers in practice to set their own pay. ${ }^{25}$ Mishel and Sabadish examined 350 firms, showing that growth in the compensation of their CEOs largely outpaced the increase in their stock market value. Most strikingly, executive compensation displayed substantial positive growth even during periods when stock market values decreased. ${ }^{26}$

There are other reasons to doubt standard marginal productivity theory. In the United States the ratio of CEO pay to that of the average worker increased from around 20 to 1 in 1965 to 354 to 1 in $2012 .{ }^{27}$ There was no change in technology that could explain a change in relative productivity of that magnitude-and no explanation for why that change in technology would occur in the US and not in other similar countries. Moreover, the design of corporate compensation schemes has made it evident that they are not intended to reward effort: typically, they are related to the performance of the stock, which rises and falls depending on many factors outside the control of the CEO, such as market interest rates and the price of oil. It would have been easy to design an incentive structure with less risk, simply by basing compensation on relative performance, relative to a group of comparable companies. ${ }^{28}$ The struggles of the Clinton administration to introduce tax systems encouraging so-called performance pay (without imposing conditions to ensure that pay was actually related to performance) and disclosure requirements (which would have enabled market participants to better assess the extent of stock dilution associated with CEO stock option plans) clarified the battle lines: those pushing for favourable tax treatment and against disclosure understood well that these arrangements would have facilitated greater inequalities in income. ${ }^{29}$ 
For specifically the rise in top incomes in the financial sector, the evidence is even more unfavourable to explanations based on marginal productivity theory. An empirical study by Philippon and Reshef shows that in the past two decades workers in the financial industry have enjoyed a huge 'pay-premium' with respect to similar sectors, which cannot be explained by the usual proxies for productivity (such as the level of education or unobserved ability). According to their estimates, financial sector compensations have been about 40 per cent higher than the level that would have been expected under perfect competition. ${ }^{30}$

It is also well documented that banks deemed 'too big to fail' enjoy a rent due to an implicit state guarantee. Investors know that these large financial institutions can count, in effect, on a government guarantee, and thus they are willing to provide them funds at lower interest rates. The big banks can thus prosper not because they are more efficient or provide better service but because they are in effect subsidised by taxpayers. There are other reasons for the super-normal returns to the large banks and their bankers. In certain of the activities of the financial sector, there is far from perfect competition. Anti-competitive practices in debit and credit cards have amplified pre-existing market power to generate huge rents. Lack of transparency (e.g. in over-the-counter Credit Default Swaps (CDSs) and derivatives) too have generated large rents, with the market dominated by four players. ${ }^{31}$ It is not surprising that the rents enjoyed in this way by big banks translated into higher incomes for their managers and shareholders.

In the financial sector even more than in other industries, executive compensation in the aftermath of the crisis provided convincing evidence against marginal productivity theory as an explanation of wages at the top: the bankers who had brought their firms and the global economy to the brink of ruin continued to receive high rates of pay - compensation which in no way could be related either to their social contribution or even their contribution to the firms for which they worked (both of which were negative). For instance, a study that focused on Bear Sterns and Lehman Brothers in 20002008 has found that the top executive managers of these two giants had brought home huge amounts of 'performance-based' compensations (estimated at around $\$ 1$ billion for Lehman and $\$ 1.4$ billion for Bear Stearns), which were not clawed back when the two firms collapsed. ${ }^{32}$

Still another piece of evidence supporting the importance of rent-seeking in explaining the increase in inequality is provided by those studies that have shown that increases in taxes at the very top do not result in decreases in growth rates. If these incomes were a result of their efforts, we might have expected those at the top to respond by working less hard, with adverse effects on GDP. ${ }^{33}$

\section{The increase in rents ${ }^{34}$}

Three striking aspects of the evolution of most rich countries in the past thirty-five years are (a) the increase in the wealth-to-income ratio; (b) the 
stagnation of median wages; and (c) the failure of the return to capital to decline. Standard neoclassical theories, in which 'wealth' is equated with 'capital', would suggest that the increase in capital should be associated with a decline in the return to capital and an increase in wages. The failure of unskilled workers' wages to increase has been attributed by some (especially in the 1990s) to skill-biased technological change, which increased the premium put by the market on skills. Hence, those with skills would see their wages rise, and those without skills would see them fall. But recent years have seen a decline in the wages paid even to skilled workers. Moreover, as my recent research shows, ${ }^{35}$ average wages should have increased, even if some wages fell. Something else must be going on.

There is an alternative - and more plausible explanation. It is based on the observation that rents are increasing (due to the increase in land rents, intellectual property rents and monopoly power). As a result, the value of those assets that are able to provide rents to their owners-such as land, houses and some financial claims-is rising proportionately. So overall wealth increases, but this does not lead to an increase in the productive capacity of the economy or in the mean marginal productivity or average wage of workers. On the contrary, wages may stagnate or even decrease, because the rise in the share of rents has happened at the expense of wages.

The assets which are driving the increase in overall wealth, in fact, are not produced capital goods. In many cases, they are not even 'productive' in the usual sense; they are not directly related to the production of goods and services. ${ }^{36}$ With more wealth put into these assets, there may be less invested in real productive capital. In the case of many countries where we have data (such as France) there is evidence that this is indeed the case: a disproportionate part of savings in recent years has gone into the purchase of housing, which has not increased the productivity of the 'real' economy.

Monetary policies that lead to low interest rates can increase the value of these 'unproductive' fixed assets - an increase in the value of wealth that is unaccompanied by any increase in the flow of goods and services. By the same token, a bubble can lead to an increase in wealth-for an extended period of time - again with possible adverse effects on the stock of 'real' productive capital. Indeed, it is easy for capitalist economies to generate such bubbles (a fact that should be obvious from the historical record, ${ }^{37}$ but which has also been confirmed in theoretical models. ${ }^{38}$ ) While in recent years there has been a 'correction' in the housing bubble (and in the underlying price of land), we cannot be confident that there has been a full correction. The increase in the wealth-income ratio may still have more to do with an increase in the value of rents than with an increase in the amount of productive capital. Those who have access to financial markets and can get credit from banks (typically those already well off) can purchase these assets, using them as collateral. As the bubble takes off, so does their wealth and society's inequality. Again, policies amplify the resulting inequality: favourable tax 
treatment of capital gains enables especially high after-tax returns on these assets and increases the wealth especially of the wealthy, who disproportionately own such assets (and understandably so, since they are better able to withstand the associated risks).

\section{The role of institutions and politics}

The large influence of rent-seeking in the rise of top incomes undermines the marginal productivity theory of income distribution. The income and wealth of those at the top comes at least partly at the expense of others-just the opposite conclusion from that which emerges from trickle-down economics. When, for instance, a monopoly succeeds in raising the price of the goods which it sells, it lowers the real income of everyone else. This suggests that institutional and political factors play an important role in influencing the relative shares of capital and labour.

As we noted earlier, in the past three decades wages have grown much less than productivity (Figure 1) - a fact which is hard to reconcile with marginal productivity theory ${ }^{39}$ but is consistent with increased exploitation. This suggests that the weakening of workers' bargaining power has been a major factor. Weak unions and asymmetric globalisation, where capital is free to move while labour is much less so, are thus likely to have contributed significantly to the great surge of inequality.

The way in which globalisation has been managed has led to lower wages in part because workers' bargaining power has been eviscerated. With capital highly mobile-and with tariffs low-firms can simply tell workers that if they don't accept lower wages and worse working conditions, the company will move elsewhere. To see how asymmetric globalisation can affect bargaining power, imagine, for a moment, what the world would be like if there was free mobility of labour, but no mobility of capital. Countries would compete to attract workers. They would promise good schools and a good environment, as well as low taxes on workers. This could be financed by high taxes on capital. But that's not the world we live in.

In most industrialised countries there has been a decline in union membership and influence; this decline has been especially strong in the Anglo-Saxon world. This has created an imbalance of economic power and a political vacuum. Without the protection afforded by a union, workers have fared even more poorly than they would have otherwise. Unions' inability to protect workers against the threat of job loss by the moving of jobs abroad has contributed to weakening the power of unions. But politics has also played a major role, exemplified in President Reagan's breaking of the air traffic controllers' strike in the US in 1981 or Margaret Thatcher's battle against the National Union of Mineworkers in the UK.

Central bank policies focusing on inflation have almost certainly been a further factor contributing to the growing inequality and the weakening of workers' bargaining power. As soon as wages start to increase, and 
especially if they increase faster than the rate of inflation, central banks focusing on inflation raise interest rates. The result is a higher average level of unemployment and a downward ratcheting effect on wages: as the economy goes into recession, real wages often fall; and then monetary policy is designed to ensure that they don't recover.

Inequalities are affected not just by the legal and formal institutional arrangements (such as the strength of unions) but also by social custom, including whether it is viewed as acceptable to engage in discrimination.

At the same time, governments have been lax in enforcing antidiscrimination laws. Contrary to the suggestion of free-market economists, but consistent with even casual observation of how markets actually behave, discrimination has been a persistent aspect of market economies, and helps explain much of what has gone on at the bottom. The discrimination takes many forms - in housing markets, in financial markets (at least one of America's large banks had to pay a very large fine for its discriminatory practices in the run-up to the crisis) and in labour markets. There is a large literature explaining how such discrimination persists. ${ }^{40,} 41$

Of course, market forces-the demand and supply for skilled workers, affected by changes in technology and education-play an important role as well, even if those forces are partially shaped by politics. But instead of these market forces and politics balancing each other out, with the political process dampening the increase in inequalities of income and wealth in periods when market forces have led to growing disparities, in the rich countries today the two have been working together to increase inequality.

\section{The price of inequality}

The evidence is thus unsupportive of explanations of inequality solely focused on marginal productivity. But what of the argument that we need inequality to grow?

A first justification for the claim that inequality is necessary for growth focuses on the role of savings and investment in promoting growth, and is based on the observation that those at the top save, while those at the bottom typically spend all of their earnings. Countries with a high share of wages will thus not be able to accumulate capital as rapidly as those with a low share of wages. The only way to generate savings required for longterm growth is thus to ensure sufficient income for the rich.

This argument is particularly inapposite today, where the problem is, to use Bernanke's term, a global savings glut. ${ }^{42}$ But even in those circumstances where growth would be increased by an increase in national savings, there are better ways of inducing savings than increasing inequality. The government can tax the income of the rich, and use the funds to finance either private or public investment; such policies reduce inequalities in consumption and disposable income, and lead to increased national savings (appropriately measured). 
A second argument centres on the popular misconception that those at the top are the job creators, and giving more money to them will thus create more jobs. Industrialised countries are full of creative entrepreneurial people throughout the income distribution. What creates jobs is demand: when there is demand, firms will create the jobs to satisfy that demand (especially if we can get the financial system to work in the way it should, providing credit to small and medium-sized enterprises).

In fact, as empirical research by the IMF has shown, inequality is associated with economic instability. In particular, IMF researchers have shown that growth spells tend to be shorter when income inequality is high. This result holds also when other determinants of growth duration (like external shocks, property rights and macroeconomic conditions) are taken into account: on average, a 10-percentile decrease in inequality increases the expected length of a growth spell by one half. ${ }^{43}$ The picture does not change if one focuses on medium-term average growth rates instead of growth duration. Recent empirical research released by the OECD shows that income inequality has a negative and statistically significant effect on medium-term growth. It estimates that in countries like the US, the UK and Italy, overall economic growth would have been six to nine percentage points higher in the past two decades had income inequality not risen. ${ }^{44}$

There are different channels through which inequality harms the economy. ${ }^{45}$ First, inequality leads to weak aggregate demand. The reason is easy to understand: those at the bottom spend a larger fraction of their income than those at the top. ${ }^{46}$ The problem may be compounded by monetary authorities' flawed responses to this weak demand. By lowering interest rates and relaxing regulations, monetary policy too easily gives rise to an asset bubble, the bursting of which leads in turn to recession. ${ }^{47}$

Many interpretations of the current crisis have indeed emphasised the importance of distributional concerns. ${ }^{48}$ Growing inequality would have led to lower consumption but for the effects of loose monetary policy and lax regulations, which led to a housing bubble and a consumption boom. It was, in short, only growing debt that allowed consumption to be sustained. ${ }^{49}$ But it was inevitable that the bubble would eventually break. And it was inevitable that, when it broke, the economy would go into a downturn.

Second, inequality of outcomes is associated with inequality of opportunity. When those at the bottom of the income distribution are at great risk of not living up to their potential, the economy pays a price not only with weaker demand today, but also with lower growth in the future. With nearly one in four American children growing up in poverty, ${ }^{50}$ many of them facing not just a lack of educational opportunity but also a lack of access to adequate nutrition and health, the country's long-term prospects are being put into jeopardy.

Third, societies with greater inequality are less likely to make public investments which enhance productivity, such as in public transportation, infrastructure, technology and education. If the rich believe that they don't 
need these public facilities, and worry that a strong government which could increase the efficiency of the economy might at the same time use its powers to redistribute income and wealth, it is not surprising that public investment is lower in countries with higher inequality. Moreover, in such countries tax and other economic policies are likely to encourage those activities that benefit the financial sector over more productive activities. In the United States today returns on long-term financial speculation (capital gains) are taxed at approximately half the rate of labour, and speculative derivatives are given priority in bankruptcy over workers. Tax laws encourage job creation abroad rather than at home. The result is a weaker and more unstable economy. Reforming these policies-and using other policies to reduce rent-seekingwould not only reduce inequality; it would improve economic performance.

It should be noted that the existence of these adverse effects of inequality on growth is itself evidence against an explanation of today's high level of inequality based on marginal productivity theory. For the basic premise of marginal productivity is that those at the top are simply receiving just deserts for their efforts, and that the rest of society benefits from their activities. If that were so, we should expect to see higher growth associated with higher incomes at the top. In fact, we see just the opposite.

\section{Reversing inequality}

A wide range of policies can help reduce inequality. Policies should be aimed at reducing inequalities both in market income and in the post-taxand-transfer incomes. The rules of the game play a large role in determining market distribution -in preventing discrimination, in creating bargaining rights for workers, in curbing monopolies and the powers of CEOs to exploit firms' other stakeholders and the financial sector to exploit the rest of society. These rules were largely rewritten during the past thirty years in ways which led to more inequality and poorer overall economic performance. Now they must be rewritten once again, to reduce inequality and strengthen the economy, for instance, by discouraging the short-termism that has become rampant in the financial and corporate sector. ${ }^{51}$

Reforms include more support for education, including pre-school; increasing the minimum wage; strengthening earned-income tax credits; strengthening the voice of workers in the workplace, including through unions; and more effective enforcement of anti-discrimination laws. But there are four areas in particular that could make inroads in the high level of inequality which now exists. ${ }^{52}$

First, executive compensation (especially in the US) has become excessive, and it is hard to justify the design of executive compensation schemes based on stock options. Executives should not be rewarded for improvements in a firm's stock market performance in which they play no part. If the Federal Reserve lowers interest rates, and that leads to an increase in stock market prices, CEOs should not get a bonus as a result. If oil prices fall, and so 
profits of airlines and the value of airline stocks increase, airline CEOs should not get a bonus. There is an easy way of taking account of these gains (or losses) which are not attributable to the efforts of executives: basing performance pay on the relative performance of firms in comparable circumstances. The design of good compensation schemes that do this has been well understood for more than a third of a century, ${ }^{53}$ and yet executives in major corporations have almost studiously resisted these insights. They have focused more on taking advantages of deficiencies in corporate governance and the lack of understanding of these issues by many shareholders to try to enhance their earnings - getting high pay when share prices increase, and also when share prices fall. In the long run, as we have seen, economic performance itself is hurt. ${ }^{54}$

Second, macroeconomic policies are needed that maintain economic stability and full employment. High unemployment most severely penalises those at the bottom and the middle of the income distribution. Today, workers are suffering thrice over: from high unemployment, weak wages and cutbacks in public services, as government revenues are less than they would be if economies were functioning well.

As we have argued, high inequality has weakened aggregate demand. Fuelling asset price bubbles through hyper-expansive monetary policy and deregulation is not the only possible response. Higher public investment-in infrastructures, technology and education-would both revive demand and alleviate inequality, and this would boost growth in the long-run and in the short-run. According to a recent empirical study by the $\mathrm{IMF}$, well-designed public infrastructure investment raises output both in the short and long term, especially when the economy is operating below potential. And it doesn't need to increase public debt in terms of GDP: well-implemented infrastructure projects would pay for themselves, as the increase in income (and thus in tax revenues) would more than offset the increase in spending. ${ }^{55}$

Third, public investment in education is fundamental to address inequality. A key determinant of workers' income is the level and quality of education. If governments ensure equal access to education, then the distribution of wages will reflect the distribution of abilities (including the ability to benefit from education) and the extent to which the education system attempts to compensate for differences in abilities and backgrounds. If, as in the United States, those with rich parents usually have access to better education, then one generation's inequality will be passed on to the next, and in each generation, wage inequality will reflect the income and related inequalities of the last.

Fourth, these much-needed public investments could be financed through fair and full taxation of capital income. This would further contribute to counteracting the surge in inequality: it can help bring down the net return to capital, so that those capitalists who save much of their income won't see their wealth accumulate at a faster pace than the growth of the overall economy, resulting in growing inequality of wealth. ${ }^{56}$ Special provisions providing for favourable taxation of capital gains and dividends not only distort 
the economy, but, with the vast majority of the benefits going to the very top, increase inequality. At the same time they impose enormous budgetary costs: 2 trillion dollars from 2013 to 2023 in the US, according to the Congressional Budget Office. ${ }^{57}$ The elimination of the special provisions for capital gains and dividends, coupled with the taxation of capital gains on the basis of accrual, not just realisations, is the most obvious reform in the tax code that would improve inequality and raise substantial amounts of revenues. There are many others, ${ }^{58}$ such as a good system of inheritance and effectively enforced estate taxation.

\section{Conclusion: redefining economic performance}

We used to think of there being a trade-off: we could achieve more equality, but only at the expense of overall economic performance. It is now clear that, given the extremes of inequality being reached in many rich countries and the manner in which they have been generated, greater equality and improved economic performance are complements.

This is especially true if we focus on appropriate measures of growth. If we use the wrong metrics, we will strive for the wrong things. As the international Commission on the Measurement of Economic Performance and Social Progress argued, there is a growing global consensus that GDP does not provide a good measure of overall economic performance. ${ }^{59}$ What matters is whether growth is sustainable, and whether most citizens see their living standards rising year after year.

Since the beginning of the new millennium, the US economy, and that of most other advanced countries, has clearly not been performing. In fact, for three decades, real median incomes have essentially stagnated. Indeed, in the case of the US, the problems are even worse and were manifest well before the recession: in the past four decades average wages have stagnated, even though productivity has drastically increased.

As this chapter has emphasised, a key factor underlying the current economic difficulties of rich countries is growing inequality. We need to focus not on what is happening on average - as GDP leads us to do-but on how the economy is performing for the typical citizen, reflected for instance in median disposable income. People care about health, fairness and security, and yet GDP statistics do not reflect their decline. Once these and other aspects of societal well-being are taken into account, recent performance in rich countries looks much worse.

The economic policies required to change this are not difficult to identify. We need more investment in public goods; better corporate governance, antitrust and anti-discrimination laws; a better regulated financial system; stronger workers' rights; and more progressive tax and transfer policies. By 'rewriting the rules' governing the market economy in these ways, it is possible to achieve greater equality in both the pre- and post-tax and transfer distribution of income, and thereby stronger economic performance. ${ }^{60}$ 


\section{Acknowledgements}

The author is indebted to Eamon Kircher-Allen and Deberati Ghosh for research assistance. Financial support from INET and the Roosevelt Institute Project on Inequality, supported by the Ford Foundation, the Bernard and Irene Schwartz Foundation, and the John D. and Catherine T. MacArthur Foundation, is gratefully acknowledged.

\section{Notes}

1 Source: T. Piketty and E. Saez, 'Income inequality in the United States, 1913-1998', Quarterly Journal of Economics, vol. 118, no. 1, 2003, pp. 1-39, Tables A3 and A6 Updated version downloaded from http://eml.berkeley.edu/ saez/ (accessed 22 December 2015). Figures are in real 2014 dollars and include capital gains.

2 Source: US Census Historical Table H-6. It should be clear that median wages could have declined, even though in a panel study, most individuals (families) would have seen an increase in their wages, if there were a sufficiently large number of new entrants into the labour force, and if these new entrants had much lower skills/education than those previously in the labour force.

3 See J. Bivens, L. Mishel and H. Shierholz, Understanding the Historic Divergence Between Productivity and a Typical Worker's Pay, Economic Policy Institute briefing paper No. 406, 2 September 2015.

4 US Census Data on educational attainment, http://www.census.gov/hhes/ socdemo/education/ (accessed 22 December 2015).

5 See The State of Working America, 12th ed by the Economic Policy Institute, http://www.stateofworkingamerica.org/chart/swa-wages-table-4-14-hourly-wageseducation/ (accessed 22 December 2015).

6 At one time, such results were explained as a result of skill-biased technical change (see G. Violante, 'Skill-biased technical change', in S. Durlauf and L. Blume, eds, The New Palgrave Dictionary of Economics, New York, Palgrave Macmillan, 2008, http://www.dictionaryofeconomics.com/article?id=pde2008_S0 00493\&goto=skillbiased\&result_number $=3340$ (accessed 6 May 2016) in which case those without skills would see their wages decline, but those with skills should see their wages increase. But an (appropriately) weighted average wage should still rise. (See J. E. Stiglitz, New Theoretical Perspectives on the Distribution of Income and Wealth among Individuals, paper presented at an IEA/World Bank Roundtable on Shared Prosperity, Jordan, 10-11 June 2014 and to be published in Inequality and Growth: Patterns and Policy, Volume 1: Concepts and Analysis, New York, Palgrave Macmillan, 2016. Data over the past fifteen years, however, during which even the wages of skilled workers have stagnated, implies that something else is going on.

7 Piketty and Saez, 'Income inequality' (updated version downloaded from http:// eml.berkeley.edu/ saez/ (accessed 22 December 2015)).

8 E. Saez and G. Zucman, 'Wealth inequality in the United States since 1913: evidence from capitalized income tax data', forthcoming in Quarterly Journal of Economics (revised October 2015). As the authors show, wealth share estimates vary slightly depending on how and whether capital gains are included in the estimate. 
9 J. Harkinson, 'The Walmart heirs are worth more than everyone in your city combined', Mother Jones, 3 October 2015, http://www.motherjones.com/politics/ 2014/10/walmart-walton-heirs-net-worth-cities (accessed 22 December 2015).

10 Saez and Zucman, 'Wealth inequality'.

11 Ibid.

12 That this is the case can be clearly seen by examining what has happened to different kinds of wealth since the end of the crisis. Stocks, which are disproportionately owned by the wealthy, have done very well. Stock market values in the United States increased by $\$ 13$ trillion from January 2009 to December 2013, according to data from the Center for Research in Security Prices. Meanwhile, home values, which account for much of middle-class wealth, have not enjoyed a strong recovery: 13.4 per cent of American homes were still underwater as of the third quarter of 2015, according to real estate company Zwillow-their owners owe more on their mortgages than the market says their houses are worth. For a concise discussion of this, see P. Dreier, 'What housing recovery?', The New York Times, 8 May 2014, http://www.nytimes.com/2014/05/09/opinion/whathousing-recovery.html?ref=opinion\&_r=0 (accessed 22 December 2015).

13 See P. Taylor, R. Kochhar, R. Fry, G. Velasco and S. Motel, 'Wealth gaps rise to record highs between whites, blacks and Hispanics', 2011, Pew Research Center report, http://www.pewsocialtrends.org/files/2011/07/SDT-Wealth-Report_726-11_FINAL.pdf (accessed 22 December 2015).

14 M. Corak, 'Income inequality, equality of opportunity, and intergenerational mobility', Journal of Economic Perspectives, vol. 27, no. 3, Summer 2013, pp. 79-102.

15 Ibid.

16 OECD Income and Poverty Statistics, http://stats.oecd.org/Index.aspx?DataSetCode=IDD\# (accessed 22 December 2015) . See also OECD, In It Together: Why Less Inequality Benefits All, Paris, OECD, 2015.

17 Piketty, T., Capital in the 21st Century, supplementary materials, Tables S9.2 and S10.1: piketty.pse.ens.fr/en/capital21c2, (accessed 14 April 2016).

18 The comparison is made using World Bank data. Some caution should be exercised in comparing different countries' Gini coefficients: in addition to the wellknown flaws in the measure, different databases have used slightly different methodologies or income data to arrive at their respective figures, and thus figures are different depending on the data source. Nevertheless, many different studies confirm these broad trends. One should also be particularly cautious in interpreting differences in Gini coefficients between developed and developing countries: Kuznets ('Economic growth and income inequality', The American Economic Review, vol. XLV, no. 1, March 1955, pp. 1-28) put forward a persuasive set of reasons why one might expect inequality to increase in the initial stages of development, as some parts of the country and some groups in the country are better able to seize new opportunities and pull away from others. Eventually, the laggards catch up. China's growth in inequality over the past thirty years is consistent with Kuznets' hypothesis; that of the advanced countries is not.

19 T. Piketty and G. Zucman, 'Wealth and inheritance in the long-run', in A. Atkinson and F. Bourguignon, eds, Handbook of Income Distribution, vol. 2, Amsterdam, Elsevier-North Holland, 2015, pp. 1303-1368.

20 See N. Senior's 1836 An Outline of the Science of Political Economy, London, Richard Griffin \& Co. 
21 For a recent application of this argument in defence of inequality, see N. G. Mankiw, 'Defending the one percent', Journal of Economic Perspectives, vol. 27, no. 3, Summer 2013, pp. 21-34.

22 I recognised this early in my own work on information asymmetries, in a major controversy with Steven N. S. Cheung over whether the institution of sharecropping (which I argued could be explained by information asymmetries) mattered (see J. E. Stiglitz, 'Incentives and risk sharing in sharecropping', The Review of Economic Studies, vol. 41, no. 2, 1974, pp. 219-55 and S. Cheung, 'Transaction costs, risk aversion and the choice of contractual arrangements', Journal of Law and Economics, vol. 19, no. 1, 1969). North has perhaps done more to bring institutional analysis into the mainstream than anyone else: see D. C. North, Institutions, Institutional Change and Economic Performance, Cambridge, Cambridge University Press, 1990.

23 J. Bakija, A. Cole and B. T. Heim, 'Job and income growth of top earners and the causes of changing income inequality: evidence from U.S. tax return data', 2012, http://web.williams.edu/Economics/wp/BakijaColeHeimJobsIncomeGrowthTop Earners.pdf (accessed 22 December 2015).

24 See M. Jensen and K. Murphy, 'Performance pay and top-management incentives', The Journal of Political Economy, vol. 98, no. 2, 1990, pp. 225-64.

25 L. Bebchuk and J. Fried, Pay without Performance: The Unfulfilled Promise of Executive Compensation, Cambridge, MA, Harvard University Press, 2006; L. Bebchuk and Y. Grinstein, The Growth of Executive Pay, NBER Working Paper No. 11443, June 2005.

26 L. Mishel and N. Sabadish, CEO Pay and the Top 1 Per Cent, Economic Policy Institute Brief 332, 2012; J. Bivens and L. Mishel, 'The pay of corporate executives and financial professionals as evidence of rents in the top 1 percent incomes', Journal of Economic Perspectives, vol. 27, no. 3, Summer 2013, pp. 57-78.

27 AFL-CIO, CEO-to-Worker Pay Ratios around the World, 2013, http://www.aflcio. org/Corporate-Watch/Paywatch-Archive/CEO-Pay-and-You/CEO-to-WorkerPayGap-in-the-United-States/Pay-Gaps-in-the-World (accessed 22 December 2015).

28 I had written a series of theoretical and policy papers arguing this in the 1980s. See e.g. B. J. Nalebuff and J. E. Stiglitz, 'Prizes and incentives: towards a general theory of compensation and competition', The Bell Journal of Economics, vol. 14, no. 1, 1983, pp. 21-43 and J. E. Stiglitz, 'The design of labor contracts: economics of incentives and risk-sharing', in H. Nalbantian, ed., Incentives, Cooperation and Risk Sharing, Totowa, NJ, Rowman \& Allanheld, 1987, pp. 47-68, reprinted in The Selected Works of Joseph E. Stiglitz, Volume II: Information and Economic Analysis: Applications to Capital, Labor, and Product Markets, Oxford, Oxford University Press, 2013, pp. 432-46.

29 The author was a participant in some of these battles. For a more extensive discussion of them, and their consequences, see J. E. Stiglitz, Roaring Nineties, New York, W. W. Norton, 2003. There were other later battles, for example concerning say in pay and other reforms in corporate governance. For a discussion of the kinds of reforms in tax and corporate governance laws that might make a difference, see J. E. Stiglitz, Rewriting the Rules, Hyde Park, NY, The Roosevelt Institute, May 2015.

30 T. Philippon and A. Reshef, 'Wages and human capital in the US financial industry: 1909-2006', The Quarterly Journal of Economics, vol. 127, no. 4, 2012, pp. 1551-609. 
31 D. Baker and T. McArthur, The Value of the Too Big to Fail' Big Bank Subsidy, Center for Economic and Policy Social Research Issue Brief, September 2009. For a different view, see United States Government Accountability Office, Large Bank Holding Companies: Expectations of Government Support, 2014, GAO-14-621, Washington, DC, United States General Accounting Office, which argues that funding advantages existed before the recent financial crash but disappeared afterwards.

32 See L. Bebchuk, A. Cohen and A. Spamaan, 'The wages of failure: executive compensation at Bear Stearns and Lehman 2000-2008', Yale Journal on Regulation, vol. 27, 2010, pp. 257-82.

33 Philippon and Reshef, 'Wages and human capital'.

34 This section is based on J. E. Stiglitz, New Theoretical Perspectives on the Distribution of Income and Wealth among Individuals, 2015, NBER Working Paper 21191.

35 Ibid.

36 Though they may be reflected in GDP, and may be related in particular to the value of housing services.

37 See C. Reinhardt and K. Rogoff, This Time Is Different: Eight Centuries of Financial Folly, 2009, Princeton, NJ, Princeton University Press.

38 See, for instance, K. Shell and J. E. Stiglitz, 'Allocation of investment in a dynamic economy', Quarterly Journal of Economics, vol. 81, no. 4, 1967, pp. 592-609; F. Hahn, 'Equilibrium dynamics with heterogeneous capital goods', Quarterly Journal of Economics, vol. 80, no. 4 1966, pp. 633-46; and Stiglitz, New Theoretical Perspectives.

39 As we noted earlier, skill-biased technological change might be able to explain declines in unskilled labour; but it is hard to reconcile either the timing of wage changes, or the stagnation even of skilled wages in recent years, with such theories. Moreover, average wages should have increased. It is, of course, possible that average productivity increased while marginal productivity did not. (This cannot, of course, happen in the Cobb-Douglas production function so beloved by macroeconomists.) But I have seen no evidence for this sudden change in technology - and no theory for why this might have happened.

40 America's mass incarceration policies have also been an important instrument of discrimination. See M. Alexander, The New Jim Crow: Mass Incarceration in the Age of Colorblindness, New York, The New Press, 2010.

41 For a recent account of this literature, see K. Basu, Beyond the Invisible Hand: Groundwork for a New Economics, Princeton, NJ, Princeton University Press, 2010. See also J. E. Stiglitz, 'Approaches to the economics of discrimination', American Economic Review, vol. 62, no. 2, 1973, pp. 287-95 and J. E. Stiglitz, 'Theories of discrimination and economic policy', in G. von Furstenberg, Ann R. Horowitz, and Bennett Harrison, eds, Patterns of Racial Discrimination, Lexington, MA, D. C. Heath and Company Lexington Books, 1974, pp. 5-26.

42 I have argued elsewhere ('Monetary policy in a multipolar world', in J. E. Stiglitz and R. S. Gurkaynak, eds, Taming Capital Flows: Capital Account Management in an Era of Globalization, IEA Conference Volume No. 154, New York, Palgrave Macmillan, 2015) that the problem is not really a savings glut: there are huge needs for investment on the global level. Unfortunately, the global financial system is unable to intermediate - to ensure that the available savings is used to finance the real global investment needs. The consequence is the 'paradox of thrift': savings leads to inadequate aggregate demand. 
43 A. Berg and J. Ostry, Inequality and Unsustainable Growth: Two Sides of the Same Coin? IMF Staff Discussion Note No. 11/08, April 2011, International Monetary Fund.

44 F. Cingano, Trends in Income Inequality and Its Impact on Economic Growth, OECD Social, Employment and Migration Working Papers, no. 163, Dec. 2014, OECD Publishing.

45 The discussion below emphasises three channels. There are others. The increased instability noted earlier has adverse consequences for growth. Extremes of inequality, especially when they seem unjustified, undermine societal trust, and this hurts growth. To the extent that inequality arises from distortionary rents, these distortions also hurt economic performance.

46 K. E. Dynan, J. Skinner and S. P. Zeldes, 'Do the rich save more?' Journal of Political Economy, vol. 112, no. 2, 2004, pp. 397-444.

47 This and other arguments in this section are developed at greater length in my book The Price of Inequality: How Today's Divided Society Endangers Our Future, New York, W. W. Norton, 2012.

48 A. Jayadev, 'Distribution and crisis: reviewing some of the linkages', in G. Epstein and M. Wolfson, eds, Handbook on the Political Economy of Crisis, Oxford, Oxford University Press, 2013, pp. 95-112. See also The Stiglitz Report: Reforming the International Monetary and Financial Systems in the Wake of the Global Crisis, with Members of the Commission of Experts of the President of the United Nations General Assembly on Reforms of the International Monetary and Financial System, New York, The New Press, 2010; and J. E. Stiglitz, Freefall: America, Free Markets, and the Sinking of the World Economy, New York, W. W. Norton, 2010.

49 See for example A. Barba and M. Pivetti, 'Rising household debt: its causes and macroeconomic implications-a long period analysis', Cambridge Journal of Economics, vol. 33, no. 1, 2009, pp. 113-37.

50 See http://www.childstats.gov/americaschildren/eco1a.asp (accessed 22 December 2015).

51 Stiglitz, Rewriting the Rules.

52 In the last chapter of my book The Price of Inequality, I outline twenty-one such policies, affecting both the distribution of income before taxes and transfers and after.

53 See, for instance, B. J. Nalebuff and J. E. Stiglitz, 'Prizes and incentives: towards a general theory of compensation and competition', The Bell Journal of Economics, vol. 14, no. 1, 1983, pp. 21-43.

54 See e.g. J. E. Stiglitz, Roaring Nineties, New York, W. W. Norton, 2003. More recently, I and my colleagues at the Roosevelt Institute have explained how other changes in tax and regulatory policy have contributed to short-sighted and dishonest corporate behaviour (see Stiglitz, Rewriting the Rules)

$55 \mathrm{IMF}$, 'Is it time for an infrastructure push? The macroeconomic effects of public investment', World Economic Outlook, October 2014, pp. 75-114, http://www. $\mathrm{imf}$. org/external/pubs/ft/weo/2014/02/pdf/c3.pdf (accessed 22 December 2015). Note that the balanced budget multiplier itself provides a framework in which governments can increase investment and stimulate the economy today, without incurring any increase in current deficits - but lowering future deficits and the debt/GDP ratio.

56 T. Piketty, Capital in the 21st Century, Cambridge, MA and London, Harvard University Press, 2014. 
57 More precisely, these are the estimated costs ('tax expenditures') associated with these special provisions. See Congressional Budget Office, The Distribution of Major Tax Expenditures in the Individual Income Tax System, May 2013, p. 31, http://cbo.gov/sites/default/files/cbofiles/attachments/TaxExpenditures_ One-Column.pdf (accessed 22 December 2015). This figure includes the effects of the 'step-up of basis at death' provision, which reduces the taxes that heirs pay on capital gains. Not including this provision, the ten-year budgetary cost of preferential treatment for capital gains and dividends is $\$ 1.34$ trillion. These calculations do not, however, include the value of the fact that the tax on capital gains is postponed until realisation.

58 See J. E. Stiglitz, Reforming Taxation to Promote Growth and Equity, Roosevelt Institute White Paper, May 2014, http://rooseveltinstitute.org/sites/all/files/ Stiglitz_Reforming_Taxation_White_Paper_Roosevelt_Institute.pdf (accessed 22 December 2015).

59 The Commission's report was released in 2009, and published as J. Stiglitz, A. Sen and J. P. Fitoussi, Mismeasuring Our Lives, New York, The New Press, 2010. The OECD has since continued work in this vein with its Better Life Initiative (http://www.oecd.org/statistics/betterlifeinitiativemeasuringwell-beingandprogress. htm (accessed 22 December 2015)) and its High Level Expert Group on the measurement of economic and social progress, convened in 2013.

60 See Stiglitz, Rewriting the Rules. 